\title{
KONTRIBUSI ACADEMIC BURNOUT DAN DUKUNGAN SOSIAL TERHADAP ACADEMIC ENGAGEMENT PADA MAHASISWA UNIVERSITAS BUANA PERJUANGAN KARAWANG
}

\author{
*Cempaka Putrie Dimala \\ **Nita Rohayati \\ *Email: cempaka.putrie@ubpkarawang.ac.id
}

\section{Fakultas Psikologi Universitas Buana Perjuangan Karawang}

\begin{abstract}
Abstact. This study aims to determine the profile of academic burnout, social support, and academic engagement and find out how much the contribution of academic burnout and social support to academic engagement in UBP Karawang students. The research population of 4,825 people, drawn from three forces, this is because UBP has only three forces. So the sample size is 354 people. The sampling technique used is proportional stratified random sampling. The data analysis method used is the Pearson Product Moment correlation technique. Based on the results of this test the hypothesis is accepted because it shows a significance value of 0,000 less than 0.05 . So it can be concluded that there is a contribution of academic burnout and social support to academic engagement in Karawang UBP students have a negative relationship direction, meaning that if academic burnout increases and social support decreases then academic engagement decreases. The contribution of academic burnout and social support variables contributed $24.9 \%$ to academic engagement, so it can be seen that $75.1 \%$ can be influenced by other variables
\end{abstract}

Keywords: Academic Engagement, Social Support, Academic Burnout.

Abstrak. Penelitian ini bertujuan untuk mengetahui profil academic burnout, dukungan sosial, dan academic engagement serta mengetahui seberapa besar kontribusi academic burnout dan dukungan sosial terhadap academic engagement pada mahasiswa UBP Karawang. Populasi penelitian sebesar 4.825 orang, yang diambil dari tiga angkatan, hal ini dikarenakan UBP baru memiliki tiga angkatan. Sehingga sample sizenya dalah 354 orang. Teknik pengambilan sampel yang digunakan adalah Proportional stratified random sampling. Metode analisis data yang digunakan adalah teknik korelasi Pearson Product Moment. Berdasarkan hasil pengujian ini hipotesis diterima karena menunjukkan nilai signifikansi 0.000 lebih kecil dari 0.05. Sehinga dapat disimpulkan bahwa ada kontribusi academic burnout dan dukungan sosial terhadap academic engagement pada mahasiswa UBP Karawang memiliki arah hubungan negatif, artinya jika academic burnout meningkat dan dukungan sosial menurun maka academic engagement menurun. Kontribusi variabel academic burnout dan dukungan sosial memiliki kontribusi sebesar 24,9\% terhadap academic engagement, sehingga dapat diketahui bahwa 75,1\% dapat dipengaruhi oleh variabel lain.

Kata Kunci: Academic Engagement, Dukungan Sosial, Academic Burnout.

1 | Psychophedia Jurnal Psikologi Universitas Buana Perjuangan Karawang 


\section{Pengantar}

Pendidikan merupakan hal yang penting pada kehidupan seseorang untuk dapat mengembangkan diri dan mempersiapkan diri untuk menghadapi perubahan zaman. Penggunaan teknologi makin pesat, sehingga mau tak mau kondisi ini harus diiringi dengan kemampuan manusia untuk dapat berkembang mengikuti pesatnya kemajuan zaman. Dengan pendidikan, maka masyarakat dapat meningkatkan kemampuan untuk dapat bersaing pada era teknologi. Sadar akan pentingnya pendidikan, mendorong masyarakat untuk mengenyam pendidikan ke jenjang yang lebih tinggi, yaitu tingkat universitas.

Pada prosesnya selama menempuh pendidikan di jenjeng Universitas baik diploma maupun strata memerlukan usaha untuk mencapai suatu keberhasilan. Usaha tersebut terkadang banyak rintangan, dan tuntutan yang harus dihadapi. Mahasiswa harus mampu menghadapinya agar nantinya dapat beradaptasi dengan lingkungan pekerjaan yang sesungguhnya. Mereka juga diharapkan mampu memenuhi berbagai tuntutan seperti pemenuhan tugas-tugas perkuliahan, menghadapi kompleksitas materi perkuliahan yang semakin sulit dari tahun ke tahun, melakukan penyesuaian sosial di lingkungan kampusnya, dan pemenuhan harapan untuk meraih pencapaian akademik (Heiman \& Kariv dalam Alfian, 2014).
Tuntutan dan rintangan yang dihadapi ini, dirasa akan sangat berat bila mahasiswa tersebut menjalani dua peran, dimana ia adalah seorang mahasiswa dan seorang karyawan/pegawai. Menjalankan dua peran sekaligus akan berakibat terhadap kurang maksimalnya salah satu dari peran tersebut. Dampak yang akan dihadapi nantinya adalah ketidakmampuan dalam menangani masalah yang akan dihadapi, dan rentan terhadap burnout. Dampak-dampak ini akan memberikan stress sendiri bagi mahasiswa, dan kondisi ini akan memicu terjadinya kegagalan dalam menempuh perkuliahan dan terancam keluar dari perguruan tinggi atau yang dikenal dengan istilah dropout.

Dropout telah banyak terjadi di beberapa perguruan tinggi di Indonesia. Ratnaningsih, Asep, dan Hari (2008) menemukan angka dropout dari tahun 2001 hingga 2007 di Universitas Terbuka mencapai $85,08 \%$, yang mayoritas dipengaruhi oleh daya tahan belajar mahasiswa. Fenomena ini senada terjadi di Universitas Buana Perjuangan Karawang, Ketua LP3M DR. Puji Isyanto,S.E.,M.M mengatakan bahwa pada awal berdirinya UBP Karawang mengalami setidaknya 1,39\% mahasiswa yang dropout, dan mengalami lonjakan kenaikan pada mahasiswa yang dropout pada tahun 2016-2, yaitu sebesar $15,72 \%$. Pihak universitas sangat menyayangkan karena hal ini terjadi pada tahun kedua berdirinya UBP Karawang. Tingginya angka dropout di UBP Karawang 
disinyalir karena permasalah academic engagement mahasiswa.

Academic engagement merupakan faktor terpenting dalam menentukan kemungkinan seorang mahasiswa mengalami dropout (Archambault, Janosz, Morizot, \& Pagani in Bilge et al, 2014). Bahkan Finn (dalam Bilge et al, 2014) menemukan hubungan yang signifikan antara academic engagement dan kesuksesan akademik, dimana semakin tinggi academic engagement mahasiswa, mereka akan semakin mampu mengatasi tuntutan dan hambatan dalam studi sehingga mereka menjadi lebih berprestasi.

Finn \& Voelkl (1993) menyatakan bahwa academic engagement adalah terpadunya sejumlah komponen psikologis yang bisa diamati dalam bentuk perilaku. Komponen tersebut meliputi komponen perilaku, tingkat kehadiran, keterlibatan emosi dan kecakapan mengidentifikasi emosi. Indikator-indikator yang dapat dijadikan pedoman untuk melihat perilaku academic engagement antara lain: partisipasi di sekolah, prestasi akademik yang tinggi, waktu yang dihabiskan untuk mengerjakan pekerjaan rumah (PR), dan tingkat terselesaikannya pekerjaan rumah (Jimerson, Campos, dan Greif, 2003).

Mahasiswa yang memiliki academic engagement rendah, mereka tidak mampu mengatasi tuntutan dan hambatan dalam studi, serta mudah terpapar burnout. Cordes (dalam Law, 2007) menyatakan bahwa burnout pada individu berhubungan dengan kemunduran hubungan interpersonal, dan pengembangan perilaku negatif yang dapat merusak individu yang bersangkutan. Banyaknya faktor-faktor yang berpotensi menimbulkan academic burnout pada mahasiswa, dapat menjadi hambatan bagi mahasiswa dalam menjalankan perkuliahannya. Mahasiswa yang mengalami burnout akan melewatkan kelas (ketidakhadiran), tidak mengerjakan tugas dengan baik, dan mendapat hasil ujian yang buruk hingga akhirnya berpotensi untuk dikeluarkan dari perguruan tinggi (Law, 2007). Dampak burnout berupa keluarnya mahasiswa dari perguruan tinggi atau yang dikenal dengan istilah dropout telah banyak terjadi di beberapa perguruan tinggi di Indonesia.

Tingginya angka dropout, membuat pihak perguruan tinggi harus memecahkan permasalah ini agar kecenderungan dropout dapat ditekan. Banyaknya faktor-faktor yang berpotensi dropout terhadap mahasiswa. Untuk dapat mengatasi permasalahan tersebut, perlu adanya pewujudan suasana belajar, dengan mendapatkan dukungan dari konteks sosial (social context) seperti dukungan orang-orang sekitar, moril, maupun, materil. Dukungan sosial pada umumnya diartikan sebagai keberadaan orang lain yang dapat dipercaya, orang yang dapat membuat seseorang merasa dipedulikan, berharga dan dicintai. Inti dari dukungan sosial adalah mengetahui bahwa orang lain mencintai dan mau melakukan sesuatu yang dapat mereka lakukan untuk kita (Sarason dkk, 1987).

Dukungan sosial yang diterima oleh mahasiswa, akan berpengaruh terhadap semua aktifitas kegiatan mahasiswa yang 
terjadi di kampus. Kondisi ini akan menempatkan posisi mahasiswa pada pembentukan persepsi terhadap semua yang sedang dijalani oleh mahasiswa tersebut. Pada akhirnya mahasiswa tersebut merasa memiliki motivasi yang mendorong seorang mahasiswa untuk menjalani perannya. Hal ini yang kemudian akan mendorong mahasiswa memiliki mastery goal orientation, yaitu suatu bagian motivasi yang mendorong seorang mahasiswa untuk menguasai materi perkuliahan sehingga ia mampu menyelesaikan suatu tugas perkuliahan dengan baik (McGregor \& Elliot, 2002; Harackiewics, Barron, Pintrich, Elliot, \& Thrash, 2002; Elliot, 2005). Apabila ia dapat menguasai berbagai materi perkuliahan dengan baik, maka ia merasa yakin dapat menghadapi tugas-tugas perkuliahan dengan baik pula (Hamachek, 1990). Karena itu, seorang mahasiswa yang memiliki orientasi menguasai materi perkuliahan, ditandai dengan jenis motivasi internal yang tumbuh atas kesadaran diri-sendiri (Harackiewics, Barron, \& Elliot, 2000).

Seseorang yang merasa yakin akan kesuksesan akademiknya, serta mampu mengatasi tuntutan dan hambatan dalam studi sehingga mereka menjadi lebih berprestasi, memiliki hubungan yang signifikan dengan academic engagement (Finn dalam Bilge et al, 2014). School engagement merupakan faktor terpenting dalam menentukan kemungkinan seorang siswa mengalami drop-out (Archambault, Janosz, Morizot, \& Pagani in Bilge et al, 2014; Fredricks, 2011).

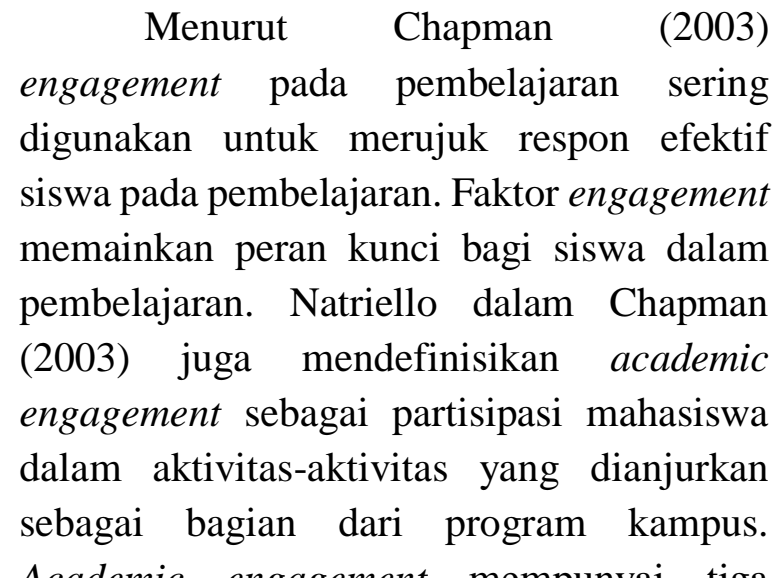
Academic engagement mempunyai tiga konstruk yaitu terdiri dari cognitive engagement, emotional engagement dan behavioral engagement (Finn, 1993; Chapman, 2003; Appleton dkk, 2008).

\section{Landasan Teori}

\section{Academic Engagement}

Academic engagement merupakan indikator yang menggabungkan identifikasi akademik (yang mengacu pada bergaul dengan guru, memiliki kepentingan dalam materi pelajaran, dan perilaku dan sikap terkait) dan berpartisipasi akademik yang menangkap usaha kerja siswa baik di dalam maupun di luar sekolah, termasuk jam yang dihabiskan untuk pekerjaan rumah, memenuhi tenggang waktu, tidak melewatkan kelas, dan sebagainya (Finn, 1989; Fredricks dkk, 2004 (Jennifer, 2007).

Peran keterlibatan dalam memahami lintasan pendidikan dan hasil siswa muncul sebagai topik yang menarik dan penting dalam beberapa dekade terakhir.Menurut Finn, dkk (dalam Jennifer, 2007) keterlibatan siswa mengacu pada kuantitas dan kualitas energi fisik dan psikologis bahwa siswa berinvestasi dalam kegiatan sekolah. 
Selanjutnya siswa berfokus hanya pada motivasi dan perilaku siswa di sekolah.

Dharmayana, Masrun, Kumara, dan Wirawan (2012) juga mengungkapkan hal senada bahwa academic engagement di sekolah merupakan proses psikologis yang ditandai dengan perhatian, minat, investasi, usaha dan keterlibatan para siswa yang dicurahkan dalam proses pekerjaan belajar di sekolah. Hart, Stewart dan Jimerson (2011) mendefinisikan perilaku academic engagement dalam tiga indikator perilaku, yaitu: strategi dalam memecahkan kesulitan akademik (Cognitive Engagement), usaha yang ditunjukan di kelas saat menghadapi tugas-tugas yang diberikan (Behavioral Engagement) dan perasaan untuk menyukai kegiatan belajar dan perasaan positif terhadap sekolah (Affective Engagement).

\section{Academic burnout}

Burnout merupakan sindrom kelelahan, baik secara fisik maupun mental yang termasuk di dalamnya berkembang konsep diri yang negatif, kurangnya konsentrasi serta perilaku yang negatif (Pines \& Maslach, 1993). Keadaan ini membuat suasana di dalam kelas menjadi dingin, tidak menyenangkan, dedikasi dan komitmen menjadi berkurang, performansi, prestasi belajar menjadi tidak maksimal. Hal ini juga membuat menjaga jarak, tidak mau terlibat dengan lingkungannya. Burnout juga dipengaruhi oleh ketidaksesuaian antara usaha dengan apa yang di dapat dari perkuliahan.

Burnout adalah sebuah metafora yang umum digunakan untuk menggambarkan keadaan kelelahan mental. Awalnya, burnout dianggap terjadi secara eksklusif dalam memberikan pelayanan kepada manusia di antara mereka yang melakukan suatu tugas perkuliahan individu hal tersebut sering terjadi di kalangan orang dewasa, mereka memiliki tanggung jawab terhadap tugas mereka sehingga fisik dan mental nya mudah tertekan dan mengalami 'kelelahan' (Schaufeli, 2004). Schaufeli, dkk (2002) menyatakan bahwa academic burnout mengacu pada perasaan lelah karena tuntutan studi, memiliki sikap sinis terhadap tugastugas perkuliahan, dan perasaan tidak kompeten sebagai mahasiswa.

Schaufeli, dkk (2002) menyatakan bahwa terdapat tiga dimensi academic burnout, yaitu: a). Exhaustion. Aitem-aitem pada dimensi ini mengacu pada perasaan lelah tetapi tidak merujuk langsung kepada orang lain sebagai sumber umum. Leiter \& Maslach (2000) menyatakan bahwa dimensi ini mengarah pada perasaan emosional yang berlebihan dan perasaan terkurasnya sumber daya emosional. Individu merasa kekurangan energi untuk menghadapi hari lain atau orang lain. b). Cynisim. Dimensi ini ditandai dengan ketidakpedulian atau sikap menjauh terhadap perkuliahan yang dijalani, tidak harus dengan orang lain. c). Reduce of Professional Efficacy. Dimensi ini meliputi aspek sosial dan nonsosial dalam pencapaian akademik. Leiter \& Maslach (2000) menyatakan bahwa individu akan merasa tidak berdaya, merasa semua tugas yang diberikan berat. Ketika merasa tidak efektif maka mereka cenderung mengembangkan rasa tidak mampu.

\section{Dukungan Sosial}

5 | Psychophedia Jurnal Psikologi Universitas Buana Perjuangan Karawang 
Definisi dukungan sosial yaitu mengacu pada kenyamanan, perhatian, penghargaan, atau bantuan yang diberikan orang lain atau kelompok kepada individu (Gentry \& Kobasa, 1984; Wallston et al., 1983; Wills \& Fegan, 2001 dalam Sarafino, 2006). Sementara dukungan sosial didefinisikan oleh Lahey (2007) sebagai peran yang dimainkan oleh teman-teman dan relatif dalam memberikan nasihat, bantuan, dan beberapa antaranya untuk menceritakan perasaan pribadi. Menurut Sarafino (2006), dukungan sosial dapat berasal dari berbagai sumber seperti pasangan hidup, keluarga, pacar, teman, rekan kerja, dan organisasi komunitas.

\section{Metode Penelitian}

Metode yang akan digunakan dalam penelitian ini adalah metode korelasional dengan tujuan untuk mengetahui sejauh mana variasi dalam satu hal berkaitan dengan variasi dalam hal lain berdasarkan koefisien korelasi (Suryabrata, 2002). Populasi penelitian adalah mahasiswa yang sedang menjalami studinya di UBP Karawang, dimana saat ini jumlah mahasiswanya sebesar 4.825 orang. Teknik yang digunakan untuk mengumpulkan data dalam penelitian ini adalah dengan menggunakan instrumen berupa skala yang mengukur academic burnout dan dukungan sosial terhadap academic engagement.

\section{Hasil Penelitian}

Pada skala academic engagement responden dengan kategori sedang sebanyak 148. Selanjutnya pada kategori tinggi sebanyak 272 responden. Menurut Finn, dkk (dalam Jennifer, 2007) Academic Engagement adalah suatu ukuran keterlibatan siswa terhadap suatu sekolah yang dapat mendorong siswa untuk mengembangkan pemahaman, pengetahuan dan dapat ikut serta berpartisipasi secara baik di dalam kegiatan - kegiatan sekolah baik tindakan maupun yang dirasakan. Pada responden dengan katagori sedang akan cukup aktif dalam kegiatan perkuliahan baik dalam pengerjaan tugas kuliah maupun kegiatan. Responden tinggi merasa bahwa kuliah merupakan tanggungjawab sehingga mampu menjalankan perkuliahan dengan sungguhsungguh, dan sangat aktif dalam kegiatan perkuliahan.

Pada skala academic burnout hanya terdapat dua kategori yaitu kategori rendah dan sedang. Kategori rendah sebanyak 191 responden dan kategori sedang sebanyak 229 responden. Menurut Schaufeli, dkk, (2002) Academic Burnout adalah perasaan lelah karena tuntutan studi, memiliki sikap sinis terhadap tugas-tugas perkuliahan, dan perasaan tidak kompeten sebagai mahasiswa. Responden dengan katagori rendah merupakan responden dengan tidak cepat merasa lelah dalam penyelesaian tugas, memiliki sikap antusias terhadap tugas-tugas perkuliahan, dan perasaan kompeten sebagai mahasiswa. Responden dengan kategori sedang merupakan responden dengan penyelesaian tugas tergantung pada kondisi kesulitan tugas yang diberikan, dan cenderung untuk menghindari tingkah laku yang berada diluar batas kemampuannya dan 
apabila tugas sulit cenderung untuk mudah digoyahkan.

Pada skala dukungan sosial responden dengan kategori sedang sebanyak 277. Selanjutnya pada kategori tinggi sebanyak 143 responden. Menurut (Sarafino, 2006) Dukungan Sosial adalah adalah adanya bantuan atau dukungan yang diterima individu dari orang lain dalam kehidupannya sehingga individu tersebut merasa bahwa orang lain memperhatikan, menghargai, dan mencintainya. Pada responden dengan dukungan sosial sedang merasa bahwa lingkungan cukup memberikan dukungan, cukup percaya terhadap kemampuan diri, sehingga merasa cukup mampu menyelesaikan masalah yang sedang dihadapi. Responden dengan kategori tinggi merasa bahwa lingkungan sepenuhnya memberikan dukungan, sangat percaya terhadap kemampuan dirinya dalam memecahkan masalah.

\section{Pembahasan}

Hasil uji antara academic burnout terhadap academic engagement pada mahasiswa UBP adalah terdapat hubungan yang negatif antara dukungan sosial dengan academic engagement pada mahasiswa UBP. Semakin tinggi academic burnout semakin rendah academic engagement mahasiswa, semakin tinggi dukungan sosial maka semakin tinggi pula academic engagement mahasiswa. Berdasarkan hasil analisis data yang telah diketahui terdapat kontribusi antara academic burnout dan dukungan sosial terhadap academic engagement pada mahasiswa UBP Karawang.
Hasil uji kolerasi menyatakan bahwa nilai koefisien signifikansi korelasi antara academic burnout dan dukungan sosial dengan academic engagement menunjukkan angka 0.00 sehingga $\alpha<0.05$ maka dapat disimpulkan bahwa terdapat kontribusi academic burnout dan dukungan sosial terhadap academic engagement pada mahasiswa UBP Karawang atau H0 ditolak dan Ha diterima. Pada uji determinasi R Square menunjukkan koefisien 0.206 yang berarti academic burnout memberikan kontribusi sebesar $20.6 \%$ terhadap academic engagement pada mahasiswa UBP Karawang. Dan untuk uji determinasi dukungan sosial menunjukkan koefisien 0.139 yang berarti dukungan sosial memberikan kontribusi sebesar $13.9 \%$ terhadap academic engagement pada mahasiswa UBP Karawang.

\begin{tabular}{lccr}
\multicolumn{1}{c}{ Uji } & koefisien & \multicolumn{2}{c}{ determinasi } \\
menunjukkan & angka & 0,499 & yang \\
menunjukkan & besaran & korelasi & antara \\
academic burnout dan & dukungan & sosial
\end{tabular} academic burnout dan dukungan sosial terhadap academic engagement pada mahasiswa UBP Karawang. Besaran korelasi tersebut menurut Sugiyono (2015) angka tersebut menunjukkan bahwa korelasi yang terjadi termasuk dalam kategori kuat. Menurut Grotbert (dalam Hendriani, 2018) Ketiga variabel tersebut berkorelasi kuat dikarenakan aspek academic burnout dan dukungan sosial juga mengukur dalam tingkat academic engagement pada mahasiswa UBP Karawang.

\section{Kesimpulan}


Berdasarkan hasil analisis data yang diperoleh dalam penelitian ini, maka dapat disimpulkan:

1. Terdapat hubungan yang negatif antara dukungan sosial dengan academic engagement pada mahasiswa UBP. Semakin tinggi academic burnout semakin rendah academic engagement mahasiswa. Sebaliknya, semakin tinggi dukungan sosial maka semakin tinggi pula academic engagement mahasiswa

2. Mahasiswa UBP Karawang didominasi oleh responden yang memiliki tingkat academic burnout yang rendah sebanyak 191 responden dan kategori sedang sebanyak 229 responden.

3. Mahasiswa UBP Karawang didominasi oleh responden yang memiliki tingkat dukungan sosial yang sedang sebanyak 277 responden dan kategori tinggi sebanyak 143 responden.

4. Mahasiswa UBP Karawang didominasi oleh responden yang memiliki tingkat academic engagement yang sedang sebanyak 148 responden dan kategori tinggi sebanyak 272 responden.

5. Variabel academic burnout mempunyai kontribusi yang negatif terhadap academic engagement dan variabel dukungan sosial mempunyai kontribusi positif terhadap academic engagement pada mahasiswa UBP Karawang. Academic burnout dan dukungan sosial memiliki arah hubungan yang negatif terhadap academic engagement mahasiswa, semakin tinggi academic burnout yang dimiliki maka semakin rendah dukungan sosial academic engagement mahasiswa. Sebaliknya, semakin rendah academic burnout yang dimiliki maka semakin tinggi dukungan sosial terhadap academic engagement mahasiswa.

\section{Kepustakaan}

Alreck, P. L., \& Settle, R. B. (2004). The survey research handbook. Boston: McGraw-Hill/Irwin

Bilge, F., Cetin, B., Dost, M. T. (2014). Factors affecting burnout and school engagement among high school students: study habits, self-efficacy beliefs, and academic success. Educational Sciences: Theory \& Practice, 1722-2727.

Azwar, S. (2012). Reliabilitas dan validitas. Ed. 4. Yogyakarta: Pustaka Pelajar.

Fredricks, J. A. (2011). Engagement in school and out-of-school contexts: a multidimensional view of engagement. Theory into Practice, 327-335.

Jennifer A. Fredricks, P. B. (2003). School engagement. The Indicators of Positive Development Conference. Child Trends.

Lippman, L., R. A. (2008, May 5). Brief Research-to-Results. Retrieved from Child Trends: www.childtrends.org 
Law, D W. (2007). Exhaustion in University students and the effect of coursework involvement. Journal of American College Health, 555(4).

Leiter, M. P., \& Maslach, C. (2000). Burnout and health. In A.

Baum, T. Revenson, \& J. Singer (Eds.) Handbook of health psychology. Hillsdale, NJ: Lawrence Earlbaum

Maslach, C., Schaufeli, W. B., \& Leiter, M. P. (2001). Job Burnout. Annual Reviews of Psychology, 52. 397422.

Ratnaningsih, D. J., Asep S., \& Hari W. (2008). Analisis daya tahan mahasiswa putus kuliah pada pendidikan tinggi jarak jauh (studi kasus: Mahasiswa jurusan manajemen fakultas Ekonomi Universitas Terbuka). Jurnal Pendidikan Terbuka dan Jarak Jauh, 9(2).

Salmela-Aro, K., Kiuru, N., Pietikäinen, M., \& Jokela, J. (2008). Does School Matter? The Role of School Context in Adolescents' SchoolRelated Burnout. Jurnal European Psychologist, 13(1).

Salmela-Aro, K., Kuntu, K. (2010). Study Burnout and Engagement in Higher Education. Unterrichtswissenschaft, 318-333.
Salmela-Aro, K., Upadyaya, K. (2013). School burnout and engagement in the context of demands-resources model. British Journal of Educational Psychology, 137-151.

Sarwono, J. (2012). Mengenal SPSS Statistics 20 Aplikasi Untuk Riset Eksperimental. Jakarta: Elex Media Komputindo.

Schaufeli, W. B. (2002). Burnout and engagement in University Students: A Cross-National Study. Journal of Cross-Cultural Psychology, 33(5).

Sugiyono. (2010). Statistika untuk penelitian. Bandung: Alfabeta.

Ugwu F. O., Ike, E. O. \& Winifred A. T. (2013). Exploring the relationships between academic burnout, selfefficacy and academic engagement among Nigerian college students. Online Journal of the African Educational Research Network, 13(2), 1-14.

Virtanen, T. U., Kiuru, N., Lerkkanen, M., Poikkeus, A., Kuorelahti, M. (2016). Assessment of student engagement among junior high school students and associations with self-esteem, burnout, and academic achievement. Journal of Educational Research Online, 136-157. 